\title{
Multisystemic inflammatory syndrome following COVID-19 mRNA vaccine in children: a national post-authorization pharmacovigilance study
}

\begin{abstract}
Naïm Ouldali, M.D., Ph.D., ${ }^{1,2,3,4}$, Haleh Bagheri, Pharm.D., Ph.D., ${ }^{5}$, Francesco Salvo, M.D., Ph.D., ${ }^{6,7}$, Denise Antona, M.D., ${ }^{8}$, Antoine Pariente, M.D., Ph.D., ${ }^{9}$, Claire Leblanc, M.D., ${ }^{1}$ Martine Tebacher, M.D., Ph.D., ${ }^{10}$, Joëlle Micallef, M.D., Ph.D., ${ }^{11,12}$, Corinne Levy, M.D., ${ }^{3,13}$ Robert Cohen, M.D., ${ }^{3,13}$, Etienne Javouhey, M.D., Ph.D., ${ }^{14,15}$, Brigitte Bader-Meunier, M.D., ${ }^{16,17}$, Caroline Ovaert, M.D., Ph.D., ${ }^{18,19}$, Sylvain Renolleau, M.D., Ph.D., ${ }^{20,21}$, Veronique Hentgen, M.D., Ph.D., ${ }^{22,23}$, Isabelle Kone-Paut, M.D.. ${ }^{23,24}$, Nina Deschamps, M.D. ${ }^{25}$, Loïc De Pontual, M.D., Ph.D., ${ }^{26}$, Xavier Iriart, M.D., ${ }^{27,28,29}$, Christelle Gras-Le Guen, M.D., Ph.D. ${ }^{30,31,32}$, François Angoulvant, M.D., Ph.D., ${ }^{1,33}$, Alexandre Belot, M.D., Ph.D., ${ }^{34,35,36}$, and the "French Covid-19 Paediatric Inflammation Consortium" Pharmacovigilance network"**
\end{abstract}

Authors affiliations:

1 Assistance Publique-Hôpitaux de Paris, Department of general paediatrics, paediatric infectious disease and internal medicine, Robert Debré university hospital, Université de Paris, Paris, France.

2 Infectious Diseases Division, CHU Sainte Justine - Montreal University, Montreal, Quebec, Canada.

3 ACTIV, Association Clinique et Thérapeutique Infantile du Val-de-Marne, Créteil, France.

4 Université de Paris, INSERM UMR 1123, ECEVE, Paris, France

5 Department of Medical and Clinical Pharmacology, Regional Pharmacovigilance Center, CIC 1436, Toulouse University Hospital, France

6 INSERM, BPH, U1219, Team Pharmacoepidemiology, Université de Bordeaux, 33000 Bordeaux, France

7 Pole de Santé Publique, Service de Pharmacologie Médicale, Regional pharmacovigilance center of Bordeaux, CHU de Bordeaux, 33000 Bordeaux, France.

8 Santé Publique France, Agence nationale de Santé publique, Saint-Maurice, France

9 Team Pharmacoepidemiology, Bordeaux University, INSERM, U1219 BPH Research Center, Bordeaux, France

10 Regional pharmacovigilance center of Strasbourg, HUS, Strasbourg, France

11 Marseille University hospital, Clinical pharmacology department Regional Pharmacovigilance Center of Marseille, France

12 Aix-Marseille University, INSERM UMR 1106, Marseille, France.

13 Centre Hospitalier Intercommunal, Research Center, Université Paris Est, IMRB-GRC GEMINI, Créteil, France.

14 Hospices Civils de Lyon, Paediatric Intensive Care Unit, Hopital Femme, Mère Enfant, University of Lyon, Bron, France

15 EA 7426 "Pathophysiology of Injury-Induced Immunosuppression", University Claude Bernard Lyon 1, Hospices Civils of Lyon, Lyon, France.

16 Department of Paediatric Hematology-Immunology and Rheumatology, Necker-Enfants Malades Hospital, AP-HP, Paris, France, Reference center for Rheumatic, AutoImmune and Systemic diseases in children (RAISE), Paris, France.

17 Laboratory of Immunogenetics of Paediatric Autoimmunity, Imagine Institute, Inserm U 1163, Paris University, Paris, France

18 Department of Pediatric Cardiology, Hôpital Timone Enfant, AP-HM, Marseille, France.

19 Aix-Marseille University, MMG, INSERM, Marseille, France.

20 Pediatric Intensive Care Unit, Necker Hospital, AP-HP, Paris University, Paris, France

21 Paris University, EA7323, Paris, France.

22 General Pediatrics department, Versailles Hospital, Paris, France.

23 CEREMAIA (French reference center for auto-inflammatory diseases and inflammatory amyloidosis), Paris, France.

24 Pediatric Rheumatology Department, Bicêtre Hospital, APHP, University of Paris Saclay, Kremlin Bicêtre, France.

25 General Pediatrics department, Saint-Malo Hospital, Saint-Malo, France.

26 General Pediatrics and Pediatric emergency department, Jean Verdier Hospital, Bondy, France.

27 Department of Pediatric and Adult Congenital Cardiology, Bordeaux University Hospital, Pessac, France

NOTE: This preprint reports new research that has not been certified by peer review and should not be used to guide clinical practice. 


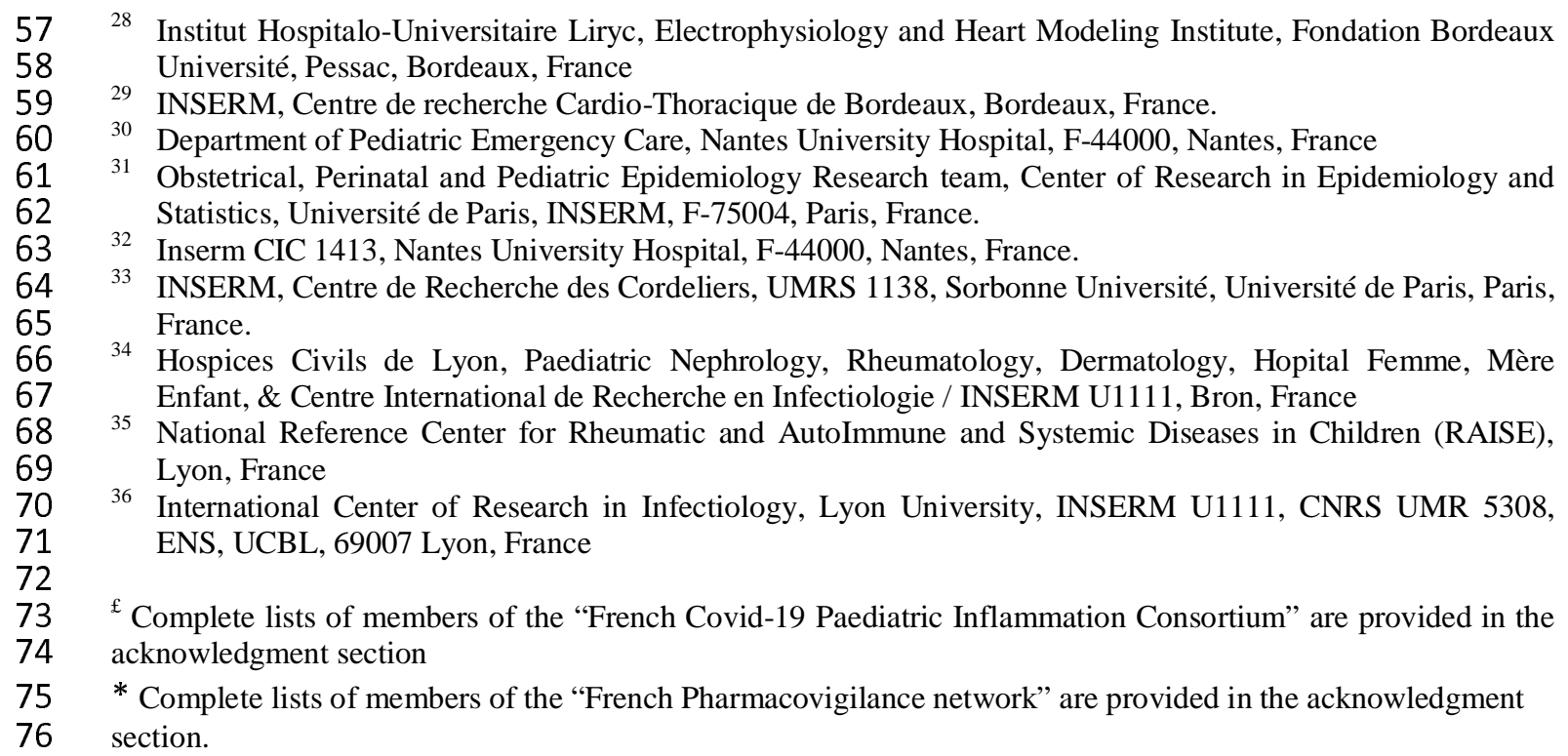

\section{Corresponding authors:}

81 Naïm Ouldali, MD, PhD, Department of General Pediatrics, Pediatric Infectious Disease and Internal Medicine, Robert Debré University Hospital, Assistance Publique-Hôpitaux de Paris, 83 F-75019 Paris, France Tel.: +-33-1-40.03.20.48; Fax: +-33-1-40.03.20.43; Email: 84 naim.ouldali@aphp.fr

85 Alexandre Belot, MD, PhD, Pediatric Nephrology, Rheumatology, Dermatology Unit, Hôpital 86 Femme Mère Enfant, Hospices Civils de Lyon, Lyon, France. Tel: +33 427856481; Email: 87 alexandre.belot@chu-lyon.fr

Word count: abstract 359. MS 3357.

90 Figure/Table count: $0 / 3$.

91 Keywords: COVID-19 mRNA vaccine, BNT162b2, multisystem inflammatory syndrome in children, hyper-inflammatory syndrome, child, SARS-COV-2. 
medRxiv preprint doi: https://doi.org/10.1101/2022.01.17.22269263; this version posted January 18, 2022. The copyright holder for this preprint

(which was not certified by peer review) is the author/funder, who has granted medRxiv a license to display the preprint in perpetuity.

All rights reserved. No reuse allowed without permission.

95 Key points:

96 Question. Is COVID-19 mRNA vaccine in 12-17-year-old children associated with subsequent

97 multisystemic hyper-inflammatory syndrome?

98 Findings. The French national pharmacovigilance system identified 9 children with a hyper99 inflammatory syndrome with multi-organ involvement following COVID-19 mRNA

100 vaccination (reporting rate $1.1[0.5 ; 2.1]$ per $1,000,000$ doses), of which only three had

101 evidence of previous SARS-CoV-2 infection. All cases fulfilled WHO definition for MIS-C, but

102 clinical and immunological features, along with short-term outcomes, slightly differed from

103 classical post SARS-CoV-2 MIS-C.

104 Meaning. Very rare cases of hyper-inflammatory syndrome can occur following COVID-19

105 mRNA vaccine in 12-17-year-old children. The very low rate of this entity, compared to 106 classical post-SARS-CoV-2 MIS-C, supports the benefit of SARS-CoV-2 vaccination in children. 
medRxiv preprint doi: https://doi.org/10.1101/2022.01.17.22269263; this version posted January 18, 2022. The copyright holder for this preprint (which was not certified by peer review) is the author/funder, who has granted medRxiv a license to display the preprint in perpetuity.

All rights reserved. No reuse allowed without permission.

\section{Abstract}

108

Importance. Multisystem inflammatory syndrome in children (MIS-C) is the most severe life-

110 threatening clinical entity associated with pediatric SARS-CoV-2 infection. Whether COVID-

11119 mRNA vaccine can induce this complication in children is unknown.

112 Objective. To assess the risk of hyper-inflammatory syndrome following COVID-19 mRNA 113 vaccine in children.

114 Design, Setting, and Participants. Post-authorization national population-based surveillance 115 using the French enhanced pharmacovigilance surveillance system for COVID-19 vaccines. All 116 cases of suspected hyper-inflammatory syndrome following COVID-19 mRNA vaccine in 12117 17-year-old children between June $15^{\text {th }}, 2021$ and January $1^{\text {st }}, 2022$, were reported. Each 118 case was assessed for WHO MIS-C criteria. Causality assessment followed 2019 WHO 119 recommendations.

120 Exposure. COVID-19 mRNA vaccine.

121 Main Outcome and Measures. The main outcome was the reporting rate of post-vaccine hyper-inflammatory syndrome per 1,000,000 COVID-19 mRNA vaccine doses in 12-17-yearold children. This reporting rate was compared to the MIS-C rate per 1,000,000 12-17-yearold children infected by SARS-CoV-2. Secondary outcomes included the comparison of clinical features between post-vaccine hyper-inflammatory syndrome and post SARS-CoV-2 MIS-C.

127 Results. From June 2021 to January 2022, 8,113,058 COVID-19 mRNA vaccine doses were 128 administered to 4,079,234 12-17-year-old children. Among them, 9 presented a 129 multisystemic hyper-inflammatory syndrome. All cases fulfilled MIS-C WHO criteria. Main 130 clinical features included male predominance $(8 / 9,89 \%)$, cardiac involvement $(8 / 9,89 \%)$, digestive symptoms $(7 / 9,78 \%)$, coagulopathy $(5 / 9,54 \%)$, cytolytic hepatitis $(4 / 9,46 \%)$, and shock (3/9, 33\%). 3/9 (33\%) required intensive care unit transfer, and 2/9 (22\%)

133 hemodynamic support. All cases recovered. Only three cases had evidence of previous SARS134 CoV-2 infection. The reporting rate was 1.1 (95\% $\mathrm{Cl}[0.5 ; 2.1])$ per 1,000,000 doses injected. 135 As a comparison, 113 MIS-C (95\%Cl [95; 135]) occurred per 1,000,000 12-17-year-old 136 children infected by SARS-CoV-2. Clinical features (inflammatory parameters, cytopenia) 137 slightly differed from post-SARS-CoV-2 MIS-C, along with short-term outcomes (less PICU 138 transfer than MIS-C). 
medRxiv preprint doi: https://doi.org/10.1101/2022.01.17.22269263; this version posted January 18, 2022. The copyright holder for this preprint (which was not certified by peer review) is the author/funder, who has granted medRxiv a license to display the preprint in perpetuity.

All rights reserved. No reuse allowed without permission.

139 Conclusion and Relevance. Very few cases of hyper-inflammatory syndromes with multi-

140 organ involvement occurred following COVID-19 mRNA vaccine in 12-17-year-old children.

141 The low reporting rate of this syndrome, compared to the rate of MIS-C among same age

142 children infected by SARS-CoV-2, supports the benefit of SARS-CoV-2 vaccination in children.

143 Further studies are required to explore specific pathways of this entity compared to post-

144 SARS-COV-2 MIS-C.

145

146 
medRxiv preprint doi: https://doi.org/10.1101/2022.01.17.22269263; this version posted January 18, 2022. The copyright holder for this preprint (which was not certified by peer review) is the author/funder, who has granted medRxiv a license to display the preprint in perpetuity.

\section{Background.}

$148 \quad$ Multisystem inflammatory syndrome in children (MIS-C) is a novel clinical entity first

149 described in April 2020..$^{1-5}$ Its association with SARS-CoV-2 infection has been documented, 150 with a previous infection occurring 4 to 6 weeks before MIS-C onset. ${ }^{4-6}$ The main clinical

151 features of MIS-C are frequent acute cardiac dysfunction, shock, multi organ failure that 152 often require pediatric intensive care unit transfer and hemodynamic support. ${ }^{7}$ Thus, $^{2}$ 153 numerous studies showed that MIS-C is by far the most severe form associated with SARS-

154 CoV-2 infection in children and the leading source of morbidity related to SARS-CoV-2 in this age group. ${ }^{7,8}$

The pathophysiology of this disease remains unknown, but previous investigations showed that MIS-C is characterized by a cytokine storm ${ }^{9}$ associated with a superantigen-like activation of T cells with an expansion of V 321.3 -expressing T cells which is not seen in toxic shock syndrome, Kawasaki disease or other COVID-19 features ${ }^{10-13}$. Notably, SARS-CoV2 spike harbors a motif located in the receptor binding domain the that is predicted in silico to interact with $V \beta$ region in $T$ cells. Whether antigenic exposure limited to the Spike protein can lead to similar dysregulated immune response remains unknown. in adults, and have been introduced since December $2020 .{ }^{14}$ Post-authorization studies confirmed their major impact on SARS-CoV-2 epidemics, ${ }^{15}$ with very few serious adverse events reported to date. ${ }^{16,17}$ In children, the immunogenicity, efficacy, as well as frequent

167 adverse events have been assessed in trials involving thousands of $12-17$-year-old children. ${ }^{18}$ 168 Based on these studies, the Food and Drug Administration (FDA) and European Medicines 169 Agency (EMA) authorized formulations of BNT162b2 COVID-19 vaccine for ages 12-17-year. 
medRxiv preprint doi: https://doi.org/10.1101/2022.01.17.22269263; this version posted January 18, 2022. The copyright holder for this preprint

(which was not certified by peer review) is the author/funder, who has granted medRxiv a license to display the preprint in perpetuity.

All rights reserved. No reuse allowed without permission.

171 these clinical trials. Especially, whether exposure to SARS-CoV-2 antigens due to mRNA

172 vaccine can induce MIS-C is unknown.

173 Given the lower burden of SARS-CoV-2 related diseases in children compared to 174 adults, elucidating the safety profile of mRNA vaccine, especially regarding MIS-C, is of

175 critical interest to establish its benefit-risk balance in this population. In this context,

176 monitoring post-vaccine MIS-C has been identified as a priority by the FDA, the EMA, and the

177 French National Agency for Medicines and Health Products safety (ANSM). ${ }^{19-21}$ Several cases

178 reports of children with MIS-C following mRNA vaccine recently raised major concerns

179 regarding this potential vaccine-related adverse event. ${ }^{22-25}$

180 Using a well-established national pharmacovigilance surveillance system coordinated

181 by $\mathrm{ANSM}^{26,27}$ we aimed to evaluate the potential association of COVID-19 mRNA vaccine

182 and subsequent hyper-inflammatory syndrome in children. 
medRxiv preprint doi: https://doi.org/10.1101/2022.01.17.22269263; this version posted January 18, 2022. The copyright holder for this preprint (which was not certified by peer review) is the author/funder, who has granted medRxiv a license to display the preprint in perpetuity.

All rights reserved. No reuse allowed without permission.

\section{Methods.}

184 Ethical review.

185 For the pharmacovigilance surveillance system, this study was performed according to the 186 authorization from the National Commission on Informatics and Liberty (CNIL) $n^{\circ} 2014-302$

187 for the national pharmacovigilance database done by ANSM. For the MIS-C following SARS-

188 CoV-2 infection surveillance system, the study was approved by the INSERM ethics 189 committee for evaluation (IRB00003888). A written information form validated by the ethics 190 committee was given to all participants. Oral consent was obtained from study participants; 191 no family members or participants refused to participate.

193 Study design and settings.

We conducted a post-authorization prospective national population-based surveillance using the well-established ANSM pharmacovigilance system. ${ }^{26,27}$ This network is based on 31 regional pharmacovigilance centers, which cover all the French territory, and is

197 coordinated by ANSM since $1973 .{ }^{26}$ All ambulatory or hospital-based health practitioners 198 throughout France or patient that observe a suspected adverse drug reaction (ADR) report 199 the event to the regional center via a secure platform. ${ }^{26}$ Reporting of all ADRs, 200 independently of the seriousness or expectedness, is compulsory for health practitioners. All 201 reports undergo a pharmacological, clinical and biological assessment process by a trained

202 assessor of the Regional Center. Cases are then registered in the national computerized 203 pharmacovigilance database, centralized at ANSM, to allow anonymized case reviewing at a 204 national level by ANSM and experts in the field, drug causality assessment, and to 205 recommend specific measures if required. ${ }^{27}$ The detailed methodology of this French 206 pharmacovigilance system has been previously published. ${ }^{26,27}$ 
medRxiv preprint doi: https://doi.org/10.1101/2022.01.17.22269263; this version posted January 18, 2022. The copyright holder for this preprint (which was not certified by peer review) is the author/funder, who has granted medRxiv a license to display the preprint in perpetuity.

All rights reserved. No reuse allowed without permission. specific reinforced surveillance system to provide real-time monitoring of COVID-19 vaccines ADRs at a national level. ${ }^{21,28}$ This is part of the risk management plan coordinated by the European Medicines Agency (EMA). The objectives are to carry out a continuous assessment of the safety of vaccines COVID-19 vaccines in order to confirm their safety or to quickly take

212 the relevant measures, and to allow the Health Ministry to adapt the vaccination strategy, if necessary. For each marketed COVID-19 vaccine, two to five regional pharmacovigilance

214 centers have been designated to gather and assess on a daily basis all adverse drug reactions reported following immunization. An expert of the organ involved is solicited to analyze the reported cases every week, to identify atypical and/or serious patterns leading to potential

217 safety signals. ${ }^{21}$ Then a weekly meeting involving ANSM and all regional pharmacovigilance centers is organized to discuss the expert pharmacovigilance reports, potential safety signals, and new data from the literature, in order to confirm or not safety signals. ${ }^{21,28} \mathrm{~A}$ complete report including the synopsis of these meeting are published by ANSM every two

weeks. $^{21,28}$ If a national safety signal is validated, appropriate measures are issued in relation

with European Medicine Agency to prevent or reduce the likelihood of the risk occurring in vaccinated people. The detailed methodology of this specific COVID-19 vaccine monitoring is available elsewhere..$^{21,28}$

225

Cases review to assess WHO criteria for MIS-C and vaccine causality.

All pediatric cases of inflammatory syndrome, fever $>3$ days, shock, or acute organ injection in children under 18 years of age in France from June $15^{\text {th }}, 2021$, to January $1^{\text {st }}$, 
medRxiv preprint doi: https://doi.org/10.1101/2022.01.17.22269263; this version posted January 18, 2022. The copyright holder for this preprint (which was not certified by peer review) is the author/funder, who has granted medRxiv a license to display the preprint in perpetuity.

All rights reserved. No reuse allowed without permission.

231 event following immunization, ${ }^{29}$ each case was reviewed by a multidisciplinary committee,

232 with experts in pediatric immunization, pediatric infectious diseases, pediatric

233 rheumatology, immunology and internal medicine, pediatric intensive care, pediatric

234 cardiology, and experts pharmacologists from pharmacovigilance centers. All these experts

235 were involved in MIS-C surveillance and management in France as part of the French MIS-C

236 consortium, and developed specific expertise in this field. ${ }^{5,30,31}$ Medical records were

237 obtained for all cases to accurately assess if cases fulfilled WHO criteria for MIS-C. Cases

238 were included after reviewing if they fulfilled WHO MIS-C criteria, with a delay between the

239 last vaccine administration and disease onset $<2$ months, based on available data from the

240 literature regarding the delay between SARS-CoV-2 infection and MIS-C onset. ${ }^{4-6}$ An

241 important part of the vaccine causality assessment relied on identifying other potential

242 causes for the event. ${ }^{29}$ For hyper-inflammatory syndrome, extensive investigation of

243 previous exposure to SARS-CoV-2 over the past two months was critical, and relied on

244 investigating history of documented infection, and performing nasopharyngeal SARS-CoV-2

245 Polymerase chain reaction (PCR) and anti-Nucleocapsid (anti-N) serology. ${ }^{32}$

246

247 National immunization program.

248 BNT162b2 COVID-19 mRNA vaccine have been introduced for 12-17-year-old children

249 on June $15^{\text {th }}, 2021$ in France. ${ }^{33}$ It has been followed by mRNA-1273 approval for same age

250 children on July, $27^{\text {th }}, 2021 .^{33}$ A higher risk of myocarditis or pericarditis has been suggested

251 following mRNA-1273 compared to BNT162b2 in adults younger than 30 years old. ${ }^{34}$ This has

252 led French authorities to prioritize BNT162b2 for 12-17-year-old children immunization.

253 Thus, by January $1^{\text {st }}, 2022$, the large majority of vaccinated $12-17$-year-old children received

254 BNT162b2 (>95\%). ${ }^{31}$ 
medRxiv preprint doi: https://doi.org/10.1101/2022.01.17.22269263; this version posted January 18, 2022. The copyright holder for this preprint (which was not certified by peer review) is the author/funder, who has granted medRxiv a license to display the preprint in perpetuity.

All rights reserved. No reuse allowed without permission.

Outcome measure.

The main outcome was the national reporting rate of hyper-inflammatory syndrome

following COVID-19 mRNA vaccine per 1,000,000 doses in 12-17-year-old children in France.

To calculate national reporting rate, we used as a denominator the total number of COVID-

19 mRNA vaccine dose administered in 12-17-year-old children over the study period

261 (available at https://solidarites-sante.gouv.fr/grands-dossiers/vaccin-covid-19/article/le-

262 tableau-de-bord-de-la-vaccination). We also estimated in the same age-group, in the same

population, the rate of post-SARS-CoV-2 MIS-C cases per 1,000,000 infections in 12-17-year-

old children in France for comparison.

265 Secondary outcomes were the reporting rate of hyper-inflammatory syndrome following

first and second injections of COVID-19 mRNA vaccine in 12-17-year-old children in France,

reporting rate by sex, and comparison of clinical features of hyper-inflammatory syndrome

following COVID-19 mRNA vaccine versus post-SARS-CoV-2 MIS-C cases.

MIS-C following SARS-CoV-2 infection surveillance system.

To estimate the rate of post-SARS-CoV-2 MIS-C cases per 1,000,000 infections in 12-

272 17-year-old children in France, we used data from the French COVID-19 Pediatric

273 Inflammation Consortium, coordinated by Public health France. ${ }^{5,30,31}$ As previously

274 published, since April 2020, all suspected MIS-C cases in France were mandatorily reported

275 to Public health France. Each suspected case was then assessed following WHO criteria for

276 MIS-C. ${ }^{5,30,31}$ Furthermore, Public health France also conducted seroprevalence studies that

277 allowed estimating the proportion of 12-17-year-old old children infected by SARS-CoV-2

278 since the beginning of the pandemic. ${ }^{35}$ Thus, to estimate the rate of post-SARS-CoV-2 MIS-C 
medRxiv preprint doi: https://doi.org/10.1101/2022.01.17.22269263; this version posted January 18, 2022. The copyright holder for this preprint (which was not certified by peer review) is the author/funder, who has granted medRxiv a license to display the preprint in perpetuity.

All rights reserved. No reuse allowed without permission.

279 cases per 1,000,000 infections, we used as a numerator the number of confirmed 12-17-

280 year-old MIS-C cases reported to Public health France since the start of the pandemic, and as

281 a denominator the estimated number of 12-17-year-old French children infected by SARS-

282 CoV-2 since the start of the pandemic. To avoid any bias in MIS-C rate estimation due to

283 vaccine implementation, ${ }^{31}$ we restricted this analysis to the pre-vaccine period, i.e. from the

284 start of the pandemic to June $15^{\text {th }}, 2021$.

285 This surveillance system also collected clinico-biological and short term outcome data

286 of MIS-C cases that fulfilled WHO criteria. ${ }^{5,30,31}$ Thus, to compare the clinical presentation of

287 hyper-inflammatory syndrome following COVID-19 mRNA vaccine to post-SARS-CoV-2 MIS-C

288 cases in the same population, we included all unvaccinated 12-17-year-old MIS-C cases

289 fulfilling WHO criteria with available clinical files as same-age and same-population

290 comparator group.

291

292 Statistical analysis.

293 We describe patient characteristics with numbers (percentages) for categorical

294 variables and median (interquartile range [IQR]) for quantitative variables. We compared

295 clinical and biological characteristics using non-parametric Fisher's exact test for categorical

296 variables and Mann-Whitney $U$ test for quantitative variables. A two-sided $p$-value $<0.05$ was

297 considered statistically significant. Reporting rate of hyper-inflammatory syndrome was

298 expressed as cases per 1,000,000 vaccine injections with $95 \%$ Cls. All statistical analyses

299 involved using R v3.6.1 (http://www.R-project.org).

300 
medRxiv preprint doi: https://doi.org/10.1101/2022.01.17.22269263; this version posted January 18, 2022. The copyright holder for this preprint (which was not certified by peer review) is the author/funder, who has granted medRxiv a license to display the preprint in perpetuity.

\section{Results.}

302 From June $15^{\text {th }}, 2021$ to January $1^{\text {st }}, 2022,8,113,058$ COVID-19 mRNA vaccine doses

303 were administered to 4,079,234 12-17-year-old children in France (including 4,079,234 first

304 injections, 3,905,636 second injections, and 128,188 third injections). Over this period, 2,028

305 adverse drug reactions related to COVID-19 mRNA vaccine have been reported to the

306 pharmacovigilance centers in 12-17-year-old children. Among them, 9 cases of hyper-

307 inflammatory syndrome were reported. All cases fulfilled WHO criteria for MIS-C (Table 1).

308 All cases involved BNT162b2 vaccine (5 cases following the first injection, 4 following the 309 second injection). The delay between last injection and disease onset ranged from 2 days to 31042 days.

312 Investigation of previous SARS-CoV-2 infection.

313 All 9 cases had complete data for history of documented infection, nasopharyngeal SARS-

314 CoV-2 PCR, and anti-N serology. In one case, a previous infection 7 months before disease

315 onset was reported, but was too far apart to be considered as linked to the disease. All 316 children had negative SARS-CoV-2 PCR, and three children had a positive anti-N serology

317 (Table 1). Based on all information available, the mRNA vaccine causality was considered 318 consistent in 4 cases, and indeterminate in 5 cases (details Table 1 and Appendix 1).

320 National reporting rate of hyper-inflammatory syndrome following mRNA vaccine

321 Considering all 9 cases of hyper-inflammatory syndrome, a national reporting rate of 1.1

$322(95 \% \mathrm{Cl}[0.5 ; 2.1])$ per 1,000,000 mRNA vaccine doses administered in 12-17-year-old 323 children was observed. Excluding cases for which evidence of previous SARS-CoV-2 infection 324 has been found, the reporting rate was reduced to $0.7(95 \% \mathrm{Cl}[0.3 ; 1.6])$ per $1,000,000$ 
medRxiv preprint doi: https://doi.org/10.1101/2022.01.17.22269263; this version posted January 18, 2022. The copyright holder for this preprint (which was not certified by peer review) is the author/funder, who has granted medRxiv a license to display the preprint in perpetuity.

All rights reserved. No reuse allowed without permission.

325 mRNA vaccine doses administered. This reporting rate varied from $1.2(95 \% \mathrm{Cl}[0.4 ; 2.9])$

326 following the first mRNA vaccine injection to $1.0(95 \% \mathrm{Cl}[0.3 ; 2.6])$ after the second mRNA

327 vaccine injection (Table 2). The reporting rate was significantly higher for males compared to

328 females $(1.9[0.8 ; 3.8]$ versus $0.3[0.0 ; 1.4]$ per $1,000,000$ doses, respectively, $p=0.039)$.

329 As a comparator, 130 post-SARS-CoV-2 MIS-C cases occurred in 12-17-year-old children, for

$3301,148,299$ same-age children infected by SARS-CoV-2, leading to a MIS-C rate of 113.3 [94.7;

331 134.6] per 1,000,000 12-17-year-old infected children (Table 2).

332

333 Clinical features of hyper-inflammatory syndrome following COVID-19 mRNA vaccine

334 compared to post-SARS-CoV-2 MIS-C cases

335 The detailed clinical presentation of children with hyper-inflammatory syndrome following

336 COVID-19 mRNA vaccine is provided Table 1. Median age was 12.5 years (IQR [12.0; 13.5]),

$3378 / 9$ (89\%) children were male and $3 / 8$ had comorbidities (one type 1 diabetes, one

338 osteochondritis with overweight, and one leukemia in remission). The most frequent clinical

339 features were cardiac involvement (8/9, 89\%, including 7 elevated cardiac enzymes, 4

340 pericarditis, 3 acute left ventricular ejection fraction decrease $\leq 55 \%, 1$ transient coronary

341 dilation and 1 myocarditis), gastrointestinal symptoms (7/9,78\%), coagulopathy $(5 / 9,56 \%)$,

342 mucocutaneous involvement (5/9,56\%), cytolytic hepatitis $(4 / 9,44 \%)$ and shock $(3 / 9,33 \%)$.

343 Macrophage activation syndrome was identified in one case. For comparison, among 199

344 children with post-SARS-CoV-2 MIS-C, 108 (54\%) were male ( $p=0.081$ ), and cardiac

345 involvement was found in $63 \%(p=0.16$, Table 3$)$.

346 Some biological parameters differed between post-vaccine hyper-inflammatory syndrome

347 and post-SARS-CoV-2 MIS-C, including inflammatory parameters (median CRP level 186 [97;

$348250]$ vs 271 [187; 354], respectively, $p=0.031$ ), and blood cell count (median hemoglobin 
medRxiv preprint doi: https://doi.org/10.1101/2022.01.17.22269263; this version posted January 18, 2022. The copyright holder for this preprint

(which was not certified by peer review) is the author/funder, who has granted medRxiv a license to display the preprint in perpetuity.

All rights reserved. No reuse allowed without permission.

$34912.3[11.6 ; 13.6]$ vs $11.0[10.1 ; 11.0]$, respectively, $p=0.022$, Table 3$)$. Of note, 2/9 (22\%)

350 children with post-vaccine hyper-inflammatory syndrome had a transient hypereosinophilia

351 (compared to 9/199 (5\%) in post-SARS-CoV-2 MIS-C). These two children were explored for

352 TRBV11-2/Vb21.3 expansion, none of them had an expansion of this repertory, while it was

353 present in $75 \%$ of post-SARS-CoV-2 MIS-C patients ${ }^{11}$.

354

355 Specific therapy and short-term outcomes.

356 Short term outcomes seemed also less severe for post-vaccine hyper-inflammatory

357 syndrome, with a lower rate of PICU transfer (3/9, 33\%), compared to $143 / 199$ (72\%) for

358 post-SARS-CoV-2 MIS-C ( $p=0.022$, Table 3 ). Six children were treated by an association of

359 intravenous immunoglobulins plus methylprednisolone, of whom one received a subsequent

$36010 \mathrm{mg} / \mathrm{kg} /$ day methylprednisolone pulse. Two children received methylprednisolone alone,

361 and one did not receive specific immunomodulator agent. All children fully recovered at the

362 time of discharge. Median length of hospital stay was 7 days (IQR [7; 9]).

363 
medRxiv preprint doi: https://doi.org/10.1101/2022.01.17.22269263; this version posted January 18, 2022. The copyright holder for this preprint (which was not certified by peer review) is the author/funder, who has granted medRxiv a license to display the preprint in perpetuity.

All rights reserved. No reuse allowed without permission.

364

365

366

367

368

369

370

371

372

373

374

375

376

377

378

379

380

381

382

383

384

385

386

387

\section{Discussion.}

To our knowledge, this is the first post-authorization population-based pharmacovigilance study assessing the risk of hyper-inflammatory syndrome following COVID-19 mRNA vaccine in 12-17-year-old children. We found that this entity was observed with an reporting rate of $1.1(95 \% \mathrm{Cl}[0.5 ; 2.1])$ per $1,000,000$ doses in this population. In most cases, no evidence of previous SARS-CoV-2 infection was observed, suggesting a link between this entity and COVID-19 mRNA vaccine. This rare serious adverse event should be put in balance with the rate of post-SARS-CoV-2 MIS-C in the same age group in the same population, which was 100 -fold higher. A recent study highlighted that COVID-19 mRNA vaccine may significantly reduce the incidence of post-SARS-CoV-2 MIS-C (Hazard Ratio 0.09 (95\% Cl, 0.04-0.21)). ${ }^{31}$ Taken together, these findings suggest that the benefit-risk balance of COVID-19 mRNA vaccine is largely in favor of the vaccination in this age group, in a context of active circulation of SARS-CoV-2.

An important issue is to delineate the clinical spectrum of this entity, which may have overlap with several other diseases. First, cases of myocarditis have been reported following COVID-19 mRNA vaccines, especially in young men. ${ }^{36,37}$ These cases mainly occurred after the second dose of vaccine, few days after the injection, and were rapidly resolutive in most cases. $^{36,37}$ The higher rate of hyper-inflammatory syndrome following COVID-19 mRNA vaccine in males, and the rate of cardiac involvement (8/9 cases) suggest similitudes with this entity. However, myocarditis were classically afebrile, with low inflammatory parameters, and were a mono-organ involvement. ${ }^{37}$ These major clinical differences may allow distinguishing these two entities. Second, all cases of hyper-inflammatory syndrome following COVID-19 mRNA vaccine fulfilled WHO definition for MIS-C. Indeed, the prolonged hyper-inflammatory state, the multi-organ involvement and the severity of the disease are 
medRxiv preprint doi: https://doi.org/10.1101/2022.01.17.22269263; this version posted January 18, 2022. The copyright holder for this preprint (which was not certified by peer review) is the author/funder, who has granted medRxiv a license to display the preprint in perpetuity.

All rights reserved. No reuse allowed without permission.

388 principal features of these two entities, ${ }^{7}$ indicating at least a major overlap. However, if

389 statistical comparison between these two diseases was limited by the low number of cases,

390 our findings suggest that post-SARS-CoV-2 MIS-C may have still higher inflammatory

391 parameters, and more cytopenia. This may be in line with the significantly lower rate of PICU

392 transfer (33\% vs 72\%) for hyper-inflammatory syndrome following COVID-19 mRNA vaccine

393 cases, which might reflect a less severe immune storm and disease course. Notably, a 4-

394 week delay has been observed in the context of MIS-C following SARS-CoV-2 infection ${ }^{38-40}$.

395 Here, the delay from first antigen exposure to hyper-inflammatory syndrome occurred

396 within a week in 3 patients and after 4-12 weeks in the 6 others. In the cases with early

397 reaction, a hypereosinophilia was seen in 2 patients, a feature not seen in classical MIS-C.

398 This observation might reflect immunoallergic reaction distinct from the superantigenic like

399 features of MIS-C. Expansion of Vb21.3 expressing T cells is a hallmark of the MIS-C and can

400 be easily assessed by flowcytometry. ${ }^{11}$ By contrast, the two children with post-vaccination

401 hyper-inflammatory syndrome had no expansion of this T cell subset. Taken together, these

402 clinical and immunological divergences may imply distinct underlying pathways and further

403 studies are required to expand this finding. Third, a recent study coordinated by the CDC

404 reported cases of multisystem inflammatory system in adults (MIS-A) in USA, in vaccinated

405 and unvaccinated adults. ${ }^{32}$ Twenty cases were identified, of whom seven were vaccinated.

406 However, all of them had a documented previous exposure to SARS-CoV-2, questioning the

407 direct causal role of mRNA vaccines in these manifestations, and diverging with the pediatric

408 syndrome reported here, with only $2 / 9$ patients presenting a seropositivity to $\mathrm{N}$ antigen. The

409 issue of delineating these different entities underline the need to extensively investigate

410 cases of hyper-inflammatory syndromes following mRNA vaccines, especially by performing

411 anti-S and anti-N serology, along with exploration for TRBV11-2/Vb21.3 expansion. 
medRxiv preprint doi: https://doi.org/10.1101/2022.01.17.22269263; this version posted January 18, 2022. The copyright holder for this preprint (which was not certified by peer review) is the author/funder, who has granted medRxiv a license to display the preprint in perpetuity.

All rights reserved. No reuse allowed without permission.

413 severe with acute multi-organ dysfunction, therapeutic aspects are of major interest. In this

414 cohort, most children were treated by an association of immunoglobulins plus

415 methylprednisolone, following MIS-C therapeutic protocols. ${ }^{30}$ Only one child treated with

416 this combination required a therapeutic escalation, and received a methylprednisolone pulse

$417(10 \mathrm{mg} / \mathrm{kg} / \mathrm{day})$. All children fully recovered. If sample size precludes any definitive

418 conclusion, these findings suggest that the association of immunoglobulins plus

419 methylprednisolone may be a suitable approach while awaiting more evidence regarding

420 these treatments.

Several limitations should be discussed. First the causality of COVID-19 mRNA

vaccines assessment was mainly based on investigation for previous SARS-CoV-2 infection.

424 However, pauci or asymptomatic infections are frequent in children, and may not have been

documented. Furthermore, false negatives can be observed for anti-Nucleocapsid serology. ${ }^{41}$

Thus, we cannot exclude that some of the cases reported here could be related to undiagnosed SARS-CoV-2 infections. Second, because this entity has not been previously described in healthy populations, we could not have a control population to estimate the expected incidence of this disease in unvaccinated children, which would help in elucidating

430 the vaccine causality. ${ }^{16}$ Third, we cannot rule out under reporting of adverse drug events in 431 our population, which may have biased the estimated rate of hyper-inflammatory syndrome.

432 However, following the implementation of COVID-19 mRNA vaccine, a major effort has been 433 made by all pharmacovigilance centers to publicize that the reporting of any suspected 434 adverse drug reaction following these vaccines was mandatory. ${ }^{26}$ The impressive number of 435 suspected adverse drug reaction reports (>80,000 between January 2021 and January 2022 
medRxiv preprint doi: https://doi.org/10.1101/2022.01.17.22269263; this version posted January 18, 2022. The copyright holder for this preprint

(which was not certified by peer review) is the author/funder, who has granted medRxiv a license to display the preprint in perpetuity.

All rights reserved. No reuse allowed without permission.

436 in France) suggest that underreporting may have been very rare, especially for serious

437 adverse drug reactions. ${ }^{26}$ Fourth, given the very low proportion of $12-17$-year-old children

438 vaccinated by mRNA-1273 (<5\%), we could not conduct subgroup analysis to compare the

439 risk of hyper-inflammatory syndromes according to COVID-19 mRNA vaccine type. Further

440 studies are required to explore if this risk differ between BNT162b2 and mRNA-1273. Fifth,

441 because mRNA vaccines were only recommended to 12-17-year-old children in France until

442 December 2021, we could not explore the risk of hyper-inflammatory syndrome in younger

443 children.

444

445 Conclusion.

446 In this study, we identified cases of hyper-inflammatory syndrome following COVID-19

447 mRNA vaccines in 12-17-year-old children in France. This syndrome was very rare, and its

448 reporting rate, in comparison with the rate of MIS-C following SARS-CoV-2 infection in the

449 same age-group, largely supports the vaccination in a context of an important circulation of

450 SARS-CoV-2. This syndrome shared many clinical features with post-SARS-CoV-2 MIS-C, but

451 some clinical, immunological and short-term outcomes divergences call for further studies to

452 explore its specific pathway.

453 
medRxiv preprint doi: https://doi.org/10.1101/2022.01.17.22269263; this version posted January 18, 2022. The copyright holder for this preprint (which was not certified by peer review) is the author/funder, who has granted medRxiv a license to display the preprint in perpetuity.

All rights reserved. No reuse allowed without permission.

454 Author Contributions:

$455 \mathrm{NO}, \mathrm{HB}, \mathrm{FA}$, and $\mathrm{AB}$ made substantial contributions to the conception or design of the work.

$456 \mathrm{NO}$ and AB drafted the manuscript. NO, HB, CLeb, CLev, EJ, BBM, CO, SR, VH, IKP, ND, LDP,

$457 \mathrm{XI}, \mathrm{CGLG}, \mathrm{FA}$ and $\mathrm{AB}$ were involved in the acquisition, analysis, or interpretation of data. All

458 authors provided critical revision of the manuscript for important intellectual content. NO

459 and HB had full access to all data in the study and take responsibility for the integrity of the

460 data and the accuracy of the data analysis.

461

462 Funding/Support: NO was supported by the 2021 ESPID (European Society for Pediatric 463 Infectious Diseases) Fellowship Award. the French Covid-19 Paediatric Inflammation 464 Consortium received an unrestricted grant from the Square Foundation (Grandir-Fonds de 465 Solidarité Pour L'enfance).

466

467 Conflicts of Interest Disclosures: NO reports travel grants from GSK, Pfizer, and Sanofi. Dr 468 Javouhey reported receiving grants from CSL Behring. Dr C. Levy reported receiving grants 469 from GlaxoSmithKline, Merck Sharp \& Dohme, and Sanofi and personal fees from Pfizer and 470 Merck. Dr Cohen reported receiving personal fees from GlaxoSmithKline, Pfizer, Sanofi, and Merck Sharp \& Dohme. All other authors have no potential conflicts of interest to disclose.

472

473 Role of the Funder/Sponsor: The funders had no role in the design or conduct of the study, collection management, analysis, or interpretation of the data; preparation, review, or approval of the manuscript; or the decision to submit the manuscript for publication.

476

477 Additional Contributions : We are grateful to Agence Nationale de Sécurité du Médicament 478 et des produits de santé (ANSM), Santé Publique France, Société Française de Pédiatrie, 479 Groupe de Pédiatrie Générale, Groupe de Pathologie Infectieuse Pédiatrique, Groupe 480 Francophone de Réanimation et d'Urgences Pédiatriques, Société Française de Cardiologie, 481 Filiale de Cardiologie Pédiatrique et Congénitale, Société Francophone Dédiée à L'étude des 482 Maladies Inflammatoires Pédiatriques, and Filière de Santé des Maladies Auto-immunes et 483 Auto-inflammatoires Rares for their participation in the French Covid-19 Paediatric 484 Inflammation Consortium study. We thank Youssef Shaim, Laurence Baril, Mehdi Benkebil, 485 Samuel Crommelynck, Baptiste Jacquot from ANSM, Isabelle Ramay, BSc, Claire Prieur, BSc, 
medRxiv preprint doi: https://doi.org/10.1101/2022.01.17.22269263; this version posted January 18, 2022. The copyright holder for this preprint (which was not certified by peer review) is the author/funder, who has granted medRxiv a license to display the preprint in perpetuity.

All rights reserved. No reuse allowed without permission.

486 Marine Borg, Aurore Prieur, BSc, Laura Meyet, LLM, Jéremy Levy, BSc, Stéphane Bechet, 487 MSc, and Sofia Abbou, LLM, from ACTIV (Association Clinique et Thérapeutique Infantile du 488 Val-de-Marne), Créteil, France; Cecile Hoffart, MSc, and Maxime Brussieux, BSc, from Clinical 489 Research Centre, Centre Hospitalier Intercommunal de Créteil, Créteil, France; Daniel Levy490 Bruhl, MD, Mireille Allemand, Scarlett Georges, BSc, Valerie Olie, PhD, Nolween Regnault, 491 PhD, and Jerome Naud, PharmD, from Santé Publique France, Agence Nationale de Santé 492 Publique, Saint-Maurice; Murielle Herasse, PhD, from Filière de Santé Des Maladies Autoimmunes et Auto-inflammatoires Rares (FAI2R), Lyon, France; and David Skurnik, PhD, from 494 INSERM U1151-Equipe 11. We are grateful to every microbiological laboratory staff member 495 who performed severe acute respiratory syndrome coronavirus 2 reverse transcriptasepolymerase chain reaction and antibody testing in each center. None of the persons listed here received compensation for their role in the study.

498

In addition to the authors, the following collaborators participated to the "French Covid-19 Pediatric Inflammation Consortium"

501 Maelle Selegny (Amiens); Lucas Jeusset, Aurelie Donzeau, Sophie Lety, Bertrand Leboucher (Angers); 502 Agnes Baur (Annecy); Cristian Fedorczuk (Arcachon); Marion Lajus, Philippe Bensaid (Argenteuil); 503 Yacine Laoudi (Aulnay Sous Bois); Charlotte Pons (Avignon); Anne-Cécile Robert, Camille Beaucourt 504 (Besançon); Loïc De Pontual (Bondy); Muriel Richard, Etienne Goisque, Xavier Iriart, Olivier Brissaud, 505 Pierre Segretin, Julie Molimard (Bordeaux); Marie-Clothilde Orecel, Gregoire Benoit (Boulognes 506 Billancourt); Lucille Bongiovanni (Brest); Guerder Margaux, Robin Pouyau, Jean-Marie De Guillebon 507 De Resnes, Ellia Mezgueldi, Fleur Cour-Andlauer, Come Horvat, Pierre Poinsot, Cecile Frachette, 508 Antoine Ouziel, Yves Gillet (Bron); Catherine Barrey (Bry Sur Marne); Jacques Brouard, Florence 509 Villedieu (Caen); Vathanaksambath Ro, Narcisse Elanga (Cayenne); Vincent Gajdos (Clamart); Romain 510 Basmaci (Colombes); Hadile Mutar (Contamine sur Arve); Sébastien Rouget (Corbeil Essone); Elodie 511 Nattes, Isabelle Hau, Sandra Biscardi, El Jurdi Houmam, Camille Jung (Créteil); Denis Semama, 512 Frederic Huet (Dijon); Anne-Marie Zoccarato (Gap); Mayssa Sarakbi (Gonnesse); Guillaume 513 Mortamet, Cécile Bost-Bru (Grenoble); Joachim Bassil (Laval); Caroline Vinit, Véronique Hentgen (Le 514 Chesnay); Pascal Leroux, Valérie Bertrand, Caroline Parrod (Le Havre); Irina Craiu, Isabelle Kone-Paut, 515 Philippe Durand, Pierre Tissiere, Caroline Claude, Guillaume Morelle, Tamazoust Guiddir, Charlotte 516 Borocco (Le Kremlin-Bicêtre); Frédérique Delion (Les Abymes); Camille Guillot, Stéphane Leteurtre, 517 François Dubos, Mylene Jouancastay, Alain Martinot, Valentine Voeusler (Lilles); Jane Languepin 518 (Limoges); Nathalie Garrec, Arnaud Chalvon Demersay (Marne La Vallée); Aurélie Morand, 
medRxiv preprint doi: https://doi.org/10.1101/2022.01.17.22269263; this version posted January 18, 2022. The copyright holder for this preprint (which was not certified by peer review) is the author/funder, who has granted medRxiv a license to display the preprint in perpetuity.

All rights reserved. No reuse allowed without permission.

519 Emmanuelle Bosdure, Noémie Vanel, Fabrice Ughetto, Fabrice Michel (Marseille); Caujolle Marie,

520 Renaud Blonde, Jacqueline Nguyen (Mayotte); Olivier Vignaud, Caroline Masserot-Lureau, François

521 Gouraud, Carine Araujo (Meaux); Tara Ingrao (Metz); Sanaa Naji (Mont de Marsans); Mohammed

522 Sehaba (Montargis); Christine Roche (Montbrison); Aurelia Carbasse, Christophe Milesi (Montpellier);

523 Mustapha Mazeghrane (Montreuil); Sandrine Haupt (Mulhouse); Cyril Schweitzer (Nancy); Benedicte

524 Romefort, Elise Launay, Christèle Gras-Le Guen (Nantes); Ahmed Ali, Nathalie Blot (Neuilly Sur Seine);

525 Antoine Tran, Anne Rancurel, Mickael Afanetti (Nice); Sophie Odorico (Nîmes); Deborah Talmud

526 (Orléans); Anais Chosidow, Anne-Sophie Romain, Emmanuel Grimprel Marie Pouletty, Jean

527 Gaschignard, Olivier Corseri, Albert Faye, Jean Gaschignard, Isabelle Melki, Camille Ducrocq, Cherine

528 Benzoïd, Johanna Lokmer, Stéphane Dauger, Maryline Chomton, Anna Deho, Fleur Lebourgeois,

529 Sylvain Renolleau, Fabrice Lesage, Florence Moulin, Laurent Dupic, Yael Pinhas, Agathe Debray,

530 Martin Chalumeau, Véronique Abadie, Pierre Frange, Jeremie F Cohen, Slimane Allali, William Curtis,

531 Zahra Belhadjer, Johanne Auriau, Mathilde Méot, Lucile Houyel, Damien Bonnet, Christophe

532 Delacourt, Brigitte Bader Meunier, Pierre Quartier, Youssef Shaim, Laurence Baril, Samuel

533 Crommelynck, Baptiste Jacquot (Paris); Philippe Blanc (Poissy); Natacha Maledon (Poitiers); Blandine

534 Robert (Pontoise); Camille Loeile (Quimper); Clémence Cazau, Gauthier Loron (Reims); Simona Gaga

535 (Remiremont); Cécile Vittot, Loubna El Nabhani (Rouen); François Buisson (Saumur); Muriel Prudent

536 (Sens); Hugues Flodrops (St Denis, La Réunion); Fadhila Mokraoui, Simon Escoda (St Denis); Nina

537 Deschamps (St Malot); Laurent Bonnemains, Sarah-Louisa Mahi, Clara Mertes, Joelle Terzic, Julie

538 Helms (Strasbourg); Charlotte Idier (Tours); Soraya Chenichene, Nicoleta Magdolena Ursulescu

539 (Trévenans); Gladys Beaujour (Villeneuve Saint Georges).

540

541 In addition to the authors, the following collaborators participated to the "French Pharmacovigilance

542 network":

543 Anaïs Gaiffe (Besançon), Antoine Pariente, Francesco Salvo (Bordeaux), Joelle Micallef (Marseille),

544 Martine Tebacher (Strasbourg), Haleh Bagheri (Toulouse), Marie-Sarah Agier (Tours).

545 
medRxiv preprint doi: https://doi.org/10.1101/2022.01.17.22269263; this version posted January 18, 2022. The copyright holder for this preprint (which was not certified by peer review) is the author/funder, who has granted medRxiv a license to display the preprint in perpetuity.

All rights reserved. No reuse allowed without permission.

\section{References.}

547 1. Riphagen S, Gomez X, Gonzalez-Martinez C, Wilkinson N, Theocharis P.

548 Hyperinflammatory shock in children during COVID-19 pandemic. Lancet. Published online

549 May 7, 2020. doi:10.1016/S0140-6736(20)31094-1

550 2. Dufort EM, Koumans EH, Chow EJ, et al. Multisystem Inflammatory Syndrome in

551 Children in New York State. N Engl J Med. 2020;383(4):347-358.

552 doi:10.1056/NEJMoa2021756

553 3. Whittaker E, Bamford A, Kenny J, et al. Clinical Characteristics of 58 Children With a

554 Pediatric Inflammatory Multisystem Syndrome Temporally Associated With SARS-CoV-2.

555 JAMA. 2020;324(3):259-269. doi:10.1001/jama.2020.10369

556 4. Feldstein LR, Rose EB, Horwitz SM, et al. Multisystem Inflammatory Syndrome in U.S.

557 Children and Adolescents. N Engl J Med. 2020;383(4):334-346. doi:10.1056/NEJMoa2021680

558 5. Belot A, Levy-Bruhl D, French Covid-19 Pediatric Inflammation Consortium.

559 Multisystem Inflammatory Syndrome in Children in the United States. N Engl J Med.

560 2020;383(18):1793-1794. doi:10.1056/NEJMc2026136

561 6. Belay ED, Abrams J, Oster ME, et al. Trends in Geographic and Temporal Distribution

562 of US Children With Multisystem Inflammatory Syndrome During the COVID-19 Pandemic.

563 JAMA Pediatr. 2021;175(8):837-845. doi:10.1001/jamapediatrics.2021.0630

$5647 . \quad$ Jiang L, Tang K, Levin M, et al. COVID-19 and multisystem inflammatory syndrome in

565 children and adolescents. Lancet Infect Dis. 2020;20(11):e276-e288. doi:10.1016/S1473-

$5663099(20) 30651-4$

567 8. Feldstein LR, Tenforde MW, Friedman KG, et al. Characteristics and Outcomes of US

568 Children and Adolescents With Multisystem Inflammatory Syndrome in Children (MIS-C)

569 Compared With Severe Acute COVID-19. JAMA. 2021;325(11):1074-1087.

570 doi:10.1001/jama.2021.2091

571 9. Consiglio CR, Cotugno N, Sardh F, et al. The Immunology of Multisystem

572 Inflammatory Syndrome in Children with COVID-19. Cell. 2020;183(4):968-981.e7.

573 doi:10.1016/j.cell.2020.09.016

574 10. Hoste L, Roels L, Naesens L, et al. TIM3+ TRBV11-2 T cells and IFN $\gamma$ signature in

575 patrolling monocytes and CD16+ NK cells delineate MIS-C. J Exp Med.

576 2022;219(2):e20211381. doi:10.1084/jem.20211381

577 11. Moreews M, Le Gouge K, Khaldi-Plassart S, et al. Polyclonal expansion of TCR Vbeta

$57821.3+$ CD4+ and CD8+ T cells is a hallmark of Multisystem Inflammatory Syndrome in

579 Children. Sci Immunol. 2021;6(59):eabh1516. doi:10.1126/sciimmunol.abh1516

580 12. Porritt RA, Paschold L, Noval Rivas M, et al. HLA class I-associated expansion of

581 TRBV11-2 T cells in Multisystem Inflammatory Syndrome in Children. J Clin Invest. Published

582 online March 11, 2021. doi:10.1172/JCl146614

583 13. Ramaswamy A, Brodsky NN, Sumida TS, et al. Immune dysregulation and

584 autoreactivity correlate with disease severity in SARS-CoV-2-associated multisystem

585 inflammatory syndrome in children. Immunity. Published online April 13, 2021.

586 doi:10.1016/j.immuni.2021.04.003

587 14. Polack FP, Thomas SJ, Kitchin N, et al. Safety and Efficacy of the BNT162b2 mRNA

588 Covid-19 Vaccine. N Engl J Med. 2020;383(27):2603-2615. doi:10.1056/NEJMoa2034577

589 15. Dagan N, Barda N, Kepten E, et al. BNT162b2 mRNA Covid-19 Vaccine in a Nationwide

590 Mass Vaccination Setting. N Engl J Med. 2021;384(15):1412-1423.

591 doi:10.1056/NEJMoa2101765 
medRxiv preprint doi: https://doi.org/10.1101/2022.01.17.22269263; this version posted January 18, 2022. The copyright holder for this preprint (which was not certified by peer review) is the author/funder, who has granted medRxiv a license to display the preprint in perpetuity.

All rights reserved. No reuse allowed without permission.

592 16. Barda N, Dagan N, Ben-Shlomo Y, et al. Safety of the BNT162b2 mRNA Covid-19

593 Vaccine in a Nationwide Setting. N Engl J Med. 2021;385(12):1078-1090.

594 doi:10.1056/NEJMoa2110475

595 17. Simone A, Herald J, Chen A, et al. Acute Myocarditis Following COVID-19 mRNA

596 Vaccination in Adults Aged 18 Years or Older. JAMA Internal Medicine. 2021;181(12):1668-

597 1670. doi:10.1001/jamainternmed.2021.5511

598 18. Frenck RW, Klein NP, Kitchin N, et al. Safety, Immunogenicity, and Efficacy of the

599 BNT162b2 Covid-19 Vaccine in Adolescents. N Engl J Med. Published online May 27,

600 2021:NEJMoa2107456. doi:10.1056/NEJMoa2107456

601 19. European Medicines Agency. Meeting highlights from the Pharmacovigilance Risk

602 Assessment Committee (PRAC) 30 August - 2 September 2021. European Medicines Agency.

603 Published 2021. Accessed December 27, 2021.

604 https://www.ema.europa.eu/en/news/meeting-highlights-pharmacovigilance-risk-

605 assessment-committee-prac-30-august-2-september-2021

606 20. FDA. Food and Drug Administration. COVID-19 vaccines. FDA. Published online 2021.

607 Accessed December 27, 2021. https://www.fda.gov/emergency-preparedness-and-

608 response/coronavirus-disease-2019-covid-19/covid-19-vaccines

609 21. Lacroix C, Salvo F, Gras-Champel V, et al. French organization for the

610 pharmacovigilance of COVID-19 vaccines: A major challenge. Therapie. 2021;76(4):297-303.

611 doi:10.1016/j.therap.2021.05.003

612 22. Abdelgalil AA, Saeedi FA. Multisystem Inflammatory Syndrome in a 12-Year-old Boy

613 After mRNA-SARS-CoV-2 Vaccination. Pediatr Infect Dis J. Published online December 21,

614 2021. doi:10.1097/INF.0000000000003442

615 23. DeJong J, Sainato R, Forouhar M, Robinson D, Kunz A. Multisystem Inflammatory

616 Syndrome in a Previously Vaccinated Adolescent Female With Sickle Cell Disease. Pediatr

617 Infect Dis J. Published online December 21, 2021. doi:10.1097/INF.0000000000003444

618 24. Yalcinkaya R, Oz FN, Polat M, et al. A Case of Multisystem Inflammatory Syndrome in

619 a 12-year-old Male After COVID-19 mRNA Vaccine. Pediatr Infect Dis J. Published online

620 December 14, 2021. doi:10.1097/INF.0000000000003432

621 25. Danish Medicine Agency. Danish Medicines Agency investigates a case of

622 inflammatory condition reported after COVID-19 vaccination. Danish Medicines Agency.

623 Published 2021. Accessed January 4, 2022.

624 https://laegemiddelstyrelsen.dk/en/news/2021/danish-medicines-agency-investigates-a-

625 case-of-inflammatory-condition-reported-after-covid-19-vaccination/

626 26. Lacroix C, Mallaret M, Jonville-Bera AP. Pharmacovigilance and drug-induced rare

627 diseases: Strengths of the French Network of Regional Pharmacovigilance Centres. Therapie.

628 2020;75(2):207-213. doi:10.1016/j.therap.2020.02.012

629 27. Abou Taam M, Jacquot B, Ferard C, et al. The French pharmacovigilance surveys: A

630 French distinctiveness, a real input. Therapie. 2021;76(5):441-447.

631 doi:10.1016/j.therap.2020.05.011

632 28. Benkebil M, Gautier S, Gras-Champel V, Massy N, Micallef J, Valnet Rabier MB.

633 COVID-19 vaccines surveillance in France: a global response to a major national challenge.

634 Anaesth Crit Care Pain Med. 2021;40(3):100866. doi:10.1016/j.accpm.2021.100866

635 29. Causality assessment of an adverse event following immunization (AEFI): user manual

636 for the revised WHO classification, 2nd ed., 2019 update. Accessed January 1, 2022.

637 https://www.who.int/publications-detail-redirect/causality-assessment-aefi-user-manual-

6382019 
medRxiv preprint doi: https://doi.org/10.1101/2022.01.17.22269263; this version posted January 18, 2022. The copyright holder for this preprint (which was not certified by peer review) is the author/funder, who has granted medRxiv a license to display the preprint in perpetuity.

All rights reserved. No reuse allowed without permission.

639 30. Ouldali N, Toubiana J, Antona D, et al. Association of Intravenous Immunoglobulins

640 Plus Methylprednisolone vs Immunoglobulins Alone With Course of Fever in Multisystem

641 Inflammatory Syndrome in Children. JAMA. 2021;325(9):855-864.

642 doi:10.1001/jama.2021.0694

643 31. Levy M, Recher M, Hubert H, et al. Multisystem Inflammatory Syndrome in Children

644 by COVID-19 Vaccination Status of Adolescents in France. JAMA. Published online December

645 20, 2021. doi:10.1001/jama.2021.23262

646 32. Belay ED, Godfred Cato S, Rao AK, et al. Multisystem Inflammatory Syndrome in

647 Adults after SARS-CoV-2 infection and COVID-19 vaccination. Clin Infect Dis. Published online

648 November 28, 2021:ciab936. doi:10.1093/cid/ciab936

649 33. Haute autorité de Santé. French SARS-CoV-2 immunization program. Haute Autorité

650 de Santé. Published 2021. Accessed December 27, 2021. https://www.has-

651 sante.fr/jcms/p_3178533/fr/vaccination-dans-le-cadre-de-la-covid-19

652 34. Le Vu S, Bertrand $M$, Jabagi MN, et al. Myocardite et péricardite après la vaccination

653 Covid-19. EPI-PHARE. Published November 8, 2021. Accessed December 27, 2021.

654 https://www.epi-phare.fr/rapports-detudes-et-publications/myocardite-pericardite-

655 vaccination-covid19/

656 35. Public health France. SARS-CoV-2 epidemics in 5-11 and 12-17-year children in

657 France. Évolution des indicateurs épidémiques chez les 5-11 ans et comparaison avec les 12-

65817 ans. Published 2021. Accessed December 29, 2021.

659 https://www.santepubliquefrance.fr/maladies-et-traumatismes/maladies-et-infections-

660 respiratoires/infection-a-coronavirus/documents/enquetes-etudes/evolution-des-

661 indicateurs-epidemiques-chez-les-5-11-ans-et-comparaison-avec-les-12-17-ans.-point-au-31-

662 octobre-2021

663 36. Mevorach D, Anis E, Cedar N, et al. Myocarditis after BNT162b2 mRNA Vaccine

664 against Covid-19 in Israel. N Engl J Med. 2021;385(23):2140-2149.

665 doi:10.1056/NEJMoa2109730

666 37. Witberg G, Barda N, Hoss S, et al. Myocarditis after Covid-19 Vaccination in a Large

667 Health Care Organization. N EnglJ Med. 2021;385(23):2132-2139.

668 doi:10.1056/NEJMoa2110737

669 38. Belot A, Antona D, Renolleau S, et al. SARS-CoV-2-related paediatric inflammatory

670 multisystem syndrome, an epidemiological study, France, 1 March to 17 May 2020.

671 Eurosurveillance. 2020;25(22):2001010. doi:10.2807/1560-7917.ES.2020.25.22.2001010

672 39. Feldstein LR, Rose EB, Horwitz SM, et al. Multisystem Inflammatory Syndrome in U.S.

673 Children and Adolescents. N Engl J Med. Published online June 29, 2020.

674 doi:10.1056/NEJMoa2021680

675 40. Dufort EM, Koumans EH, Chow EJ, et al. Multisystem Inflammatory Syndrome in

676 Children in New York State. N Engl J Med. Published online June 29, 2020.

677 doi:10.1056/NEJMoa2021756

678 41. Petersen LR, Sami S, Vuong N, et al. Lack of Antibodies to Severe Acute Respiratory

679 Syndrome Coronavirus 2 (SARS-CoV-2) in a Large Cohort of Previously Infected Persons. Clin

680 Infect Dis. 2021;73(9):e3066-e3073. doi:10.1093/cid/ciaa1685

681

682 
Table 1. Characteristics of children with hyper inflammatory syndrome following COVID-19 mRNA in France.

\begin{tabular}{|c|c|c|c|c|c|c|c|c|c|}
\hline Case & 1 & 2 & 3 & 4 & 5 & 6 & 7 & 8 & 9 \\
\hline Sex & Male & Male & Male & Male & Male & Male & Female & Male & Male \\
\hline Comorbidity & No & No & No & No & Type 1 diabetes & Osteoch ondritis & Leukemia & No & No \\
\hline Overweight & No & No & No & No & No & Yes & No & No & No \\
\hline $\begin{array}{l}\text { Number of } \\
\text { COVID-19 mRNA } \\
\text { injection }\end{array}$ & 2 & 1 & 1 & 2 & 1 & 1 & 1 & 2 & 2 \\
\hline $\begin{array}{l}\text { COVID-19 mRNA } \\
\text { vaccine }\end{array}$ & BNT162b2 & BNT162b2 & BNT162b2 & BNT162b2 & BNT162b2 & BNT162b2 & BNT162b2 & BNT162b2 & BNT162b2 \\
\hline $\begin{array}{l}\text { Delay from } \\
\text { COVID-19 mRNA } \\
\text { last injection to } \\
\text { symptoms onset }\end{array}$ & $\begin{array}{l}26 \text { days ( } 50 \text { days } \\
\text { from first } \\
\text { injection) }\end{array}$ & 6 days & 6 days & $\begin{array}{l}2 \text { days ( } 24 \text { days } \\
\text { from first injection) }\end{array}$ & 4 days & 20 days & 19 days & $\begin{array}{l}42 \text { days ( } 72 \text { days } \\
\text { from first injection) }\end{array}$ & $\begin{array}{l}7 \text { days (28 days } \\
\text { from first } \\
\text { injection) }\end{array}$ \\
\hline $\begin{array}{l}\text { MIS-C WHO } \\
\text { criteria }\end{array}$ & Yes & Yes & Yes & Yes & Yes & Yes & Yes & Yes & Yes \\
\hline $\begin{array}{l}\text { Details of MIS-C } \\
\text { WHO criteria }\end{array}$ & $\begin{array}{l}\text { Fever }>3 \text { days, } \\
\text { mucocutaneous } \\
\text { involvement, } \\
\text { Cardiac } \\
\text { involvement, } \\
\text { Elevated markers } \\
\text { of inflammation, } \\
\text { No other obvious } \\
\text { microbial cause }\end{array}$ & $\begin{array}{l}\text { Fever }>3 \text { days, } \\
\text { Shock, } \\
\text { Cardiac } \\
\text { involvement, } \\
\text { Coagulopathy, } \\
\text { Acute } \\
\text { gastrointestinal } \\
\text { symptoms, } \\
\text { Elevated markers of } \\
\text { inflammation, } \\
\text { No other obvious } \\
\text { microbial cause }\end{array}$ & $\begin{array}{l}\text { Fever }>3 \text { days, } \\
\text { mucocutaneous } \\
\text { involvement, } \\
\text { Shock, } \\
\text { Cardiac } \\
\text { involvement, } \\
\text { Coagulopathy, } \\
\text { Acute } \\
\text { gastrointestinal } \\
\text { symptoms, } \\
\text { Elevated markers } \\
\text { of inflammation, } \\
\text { No other obvious } \\
\text { microbial cause }\end{array}$ & $\begin{array}{l}\text { Fever }>3 \text { days, } \\
\text { Cardiac } \\
\text { involvement, } \\
\text { Coagulopathy, } \\
\text { Acute } \\
\text { gastrointestinal } \\
\text { symptoms, } \\
\text { Elevated markers of } \\
\text { inflammation, } \\
\text { No other obvious } \\
\text { microbial cause }\end{array}$ & $\begin{array}{l}\text { Fever }>3 \text { days, } \\
\text { mucocutaneous } \\
\text { involvement, Shock, } \\
\text { Cardiac involvement, } \\
\text { Acute gastrointestinal } \\
\text { symptoms, } \\
\text { Elevated markers of } \\
\text { inflammation, } \\
\text { No other obvious } \\
\text { microbial cause }\end{array}$ & $\begin{array}{l}\text { Fever }>3 \text { days, } \\
\text { mucocutaneous } \\
\text { involvement, } \\
\text { Cardiac } \\
\text { involvement, } \\
\text { Elevated } \\
\text { markers of } \\
\text { inflammation, } \\
\text { No other } \\
\text { obvious } \\
\text { microbial cause }\end{array}$ & $\begin{array}{l}\text { Fever }>3 \text { days, } \\
\text { Coagulopathy, } \\
\text { Acute } \\
\text { gastrointestinal } \\
\text { symptoms, } \\
\text { Elevated } \\
\text { markers of } \\
\text { inflammation, } \\
\text { No other } \\
\text { obvious } \\
\text { microbial cause }\end{array}$ & $\begin{array}{l}\text { Fever }>3 \text { days, } \\
\text { Coagulopathy, } \\
\text { Cardiac } \\
\text { involvement, } \\
\text { Acute } \\
\text { gastrointestinal } \\
\text { symptoms, } \\
\text { Elevated markers of } \\
\text { inflammation, } \\
\text { No other obvious } \\
\text { microbial cause }\end{array}$ & 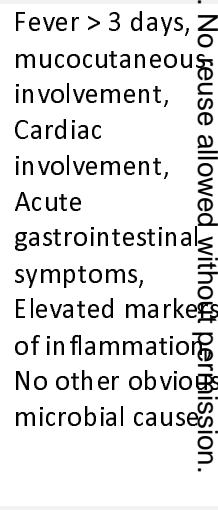 \\
\hline $\begin{array}{l}\text { Other } \\
\text { manifestations }\end{array}$ & $\begin{array}{l}\text { Lymphopenia, } \\
\text { Cervical } \\
\text { lymphadenopathy }\end{array}$ & $\begin{array}{l}\text { Acute renal failure, } \\
\text { proteinuria, } \\
\text { Cytolytic hepatitis, } \\
\text { Neurological } \\
\text { involvement, } \\
\text { Polyserositis, } \\
\text { Hypereosinophilia. }\end{array}$ & $\begin{array}{l}\text { Lymphopenia, } \\
\text { Coronary dilation. }\end{array}$ & $\begin{array}{l}\text { Acute renal failure, } \\
\text { Cytolytic hepatitis, } \\
\text { Pyelitis, } \\
\text { lleo-colitis. }\end{array}$ & $\begin{array}{l}\text { Cervical } \\
\text { lymphadenopathy, } \\
\text { Hypereosinophilia, } \\
\text { Acute generalized } \\
\text { exanthematous } \\
\text { pustulosis. }\end{array}$ & Lymphopenia. & $\begin{array}{l}\text { Macrophage } \\
\text { activation } \\
\text { syndrome, } \\
\text { Cytolytic } \\
\text { hepatitis. }\end{array}$ & $\begin{array}{l}\text { Lymphopenia, } \\
\text { Cervical } \\
\text { lymphadenopathy } \\
\text { Cytolytic hepatitis. }\end{array}$ & $\begin{array}{l}\text { Lymphopenia, } \\
\text { lleitis. }\end{array}$ \\
\hline \multicolumn{10}{|l|}{$\begin{array}{l}\text { Biological } \\
\text { features }\end{array}$} \\
\hline $\mathrm{CRP}, \mathrm{mg} / \mathrm{L}$ & 250 & 300 & 257 & 228 & 70 & 97 & 49 & 167 & 186 \\
\hline Ferritinemia & 527 & 195 & 600 & Not performed & 309 & 9185 & 25020 & 430 & Not performed \\
\hline
\end{tabular}




\begin{tabular}{|c|c|c|c|c|c|c|c|c|c|c|}
\hline \multicolumn{11}{|l|}{$(\mu \mathrm{g} / \mathrm{L})$} \\
\hline $\begin{array}{l}\text { Hemoglobin } \\
(\mathrm{g} / \mathrm{dL})\end{array}$ & 12.6 & 11.6 & 10.6 & 14.6 & NA & NA & 15.6 & 12.3 & 11.5 & \\
\hline $\begin{array}{l}\text { Leucocytes } \\
\text { (/mm3) }\end{array}$ & 16500 & 11130 & 16600 & 4050 & NA & 12800 & 1250 & 10000 & 8690 & \\
\hline $\begin{array}{l}\text { Neutrophils } \\
(/ \mathrm{mm} 3)\end{array}$ & 15500 & 4340 & 13000 & Not performed & NA & 9700 & 1040 & 9400 & 7600 & \\
\hline $\begin{array}{l}\text { Lymphocytes } \\
\text { (/mm3) }\end{array}$ & 520 & 3560 & 900 & Not performed & NA & 890 & 100 & 920 & 540 & \\
\hline $\begin{array}{l}\text { Eosinophils } \\
\text { (/mm3) }\end{array}$ & 20 & 2000 & 310 & Not performed & 1170 & NA & 0 & 220 & 10 & \\
\hline $\begin{array}{l}\text { Platelets } \\
(/ \mathrm{mm} 3)\end{array}$ & 225000 & 472000 & 278000 & 321000 & 204000 & 350000 & 27000 & 230000 & 113000 & ? \\
\hline \multicolumn{10}{|l|}{$\begin{array}{l}\text { SARS-CoV-2 } \\
\text { infection } \\
\text { documentation }\end{array}$} & 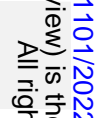 \\
\hline $\begin{array}{l}\text { Past history of } \\
\text { SARS-CoV-2 } \\
\text { infection }\end{array}$ & No & No & No & No & $\begin{array}{l}\text { Yes (documented } \\
\text { SARS-CoV-2 infection } \\
7 \text { months before) }\end{array}$ & No & No & No & No & \\
\hline $\begin{array}{l}\text { Nasopharyngeal } \\
\text { SARS-CoV-2 PCR }\end{array}$ & Negative & Negative & Negative & Negative & Negative & Negative & Negative & Negative & Negative & \\
\hline $\begin{array}{l}\text { SARS-CoV-2 } \\
\text { antibody }\end{array}$ & $\begin{array}{l}\text { Anti-Spike: } \\
\text { positive } \\
\text { Anti-N: negative }\end{array}$ & $\begin{array}{l}\text { Anti-Spike: positive } \\
\text { Anti-N: negative }\end{array}$ & $\begin{array}{l}\text { Anti-Spike: } \\
\text { positive } \\
\text { Anti-N: positive }\end{array}$ & $\begin{array}{l}\text { Anti-Spike: positive } \\
\text { Anti-N: positive }\end{array}$ & $\begin{array}{l}\text { Anti-Spike: positive } \\
\text { Anti-N: negative }\end{array}$ & $\begin{array}{l}\text { Anti-Spike: } \\
\text { positive } \\
\text { Anti-N: negative }\end{array}$ & $\begin{array}{l}\text { Anti-Spike: } \\
\text { negative } \\
\text { Anti-N: negative }\end{array}$ & $\begin{array}{l}\text { Anti-Spike: positive } \\
\text { Anti-N: limit of } \\
\text { significance* }\end{array}$ & $\begin{array}{l}\text { Anti-Spike: } \\
\text { positive } \\
\text { Anti-N: positiv }\end{array}$ & 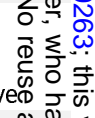 \\
\hline Specific therapy & IVIG+ steroids & None & IVIG + steroids & IVIG+ steroids & $\begin{array}{l}\text { IVIG+ steroids } \\
\text { followed by steroid } \\
\text { pulse }\end{array}$ & IVIG+ steroids & Steroids & IVIG+ steroids & Steroid pulse & 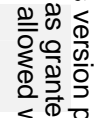 \\
\hline PICU transfer & Yes & Yes & No & No & Yes & No & No & No & No & 局 \\
\hline LVEF $\leq 55 \%$ & Yes $(55 \%)$ & NON & No & Yes $(40 \%)$ & Yes & No & No & No & Yes $(40 \%)$ & 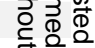 \\
\hline $\begin{array}{l}\text { Hemodynamic } \\
\text { support }\end{array}$ & No & Yes & No & No & Yes & No & No & No & No & \\
\hline Outcome & Favorable & Favorable & Favorable & Favorable & Favorable & Favorable & Favorable & Favorable & Favorable & \\
\hline $\begin{array}{l}\text { Causality of } \\
\text { COVID-19 mRNA } \\
\text { (WHO AEFI } \\
\text { classification) }\end{array}$ & $\mathrm{A} 1$ & $\mathrm{~A} 1$ & B2 & B2 & $\mathrm{A} 1$ & $\mathrm{~A} 1$ & B1 & B1 & B2 & 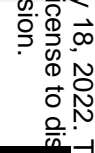 \\
\hline \multicolumn{10}{|c|}{$\begin{array}{l}\text { *: antibody titer: } 1.2 \text { (Norms of the laboratory: positive: } \geq 1.68 \text {, negative: }<0.49 \text {, limit: } 0.49 \leq \\
\text { Abbreviations: PCR: polymerase chain reaction. Anti-N: anti nucleocapsid. NA: missing data. }\end{array}$} & 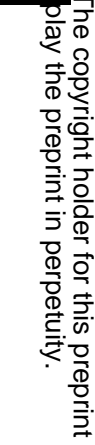 \\
\hline
\end{tabular}


medRxiv preprint doi: https://doi.org/10.1101/2022.01.17.22269263; this version posted January 18, 2022. The copyright holder for this preprint (which was not certified by peer review) is the author/funder, who has granted medRxiv a license to display the preprint in perpetuity.

All rights reserved. No reuse allowed without permission.

Table 2: Rate of hyper-inflammatory syndrome following COVID-19 mRNA vaccine compared to MIS-C post SARS-CoV-2 infection in 12-17-year-old children in France.

A) Reporting rate of hyper-inflammatory syndrome following COVID-19 mRNA vaccine in 12-17-year-old children

\begin{tabular}{|c|c|c|c|}
\hline & $\begin{array}{l}\text { Number of } \\
\text { injected doses }\end{array}$ & $\begin{array}{l}\text { Number of hyper- } \\
\text { inflammatory syndrome }\end{array}$ & $\begin{array}{l}\text { Reporting rate per } \\
1,000,000 \text { doses }\end{array}$ \\
\hline Overall vaccination & $8,113,058$ & 9 & $1.1[0.5 ; 2.1]$ \\
\hline $\begin{array}{l}\text { Excluding cases for which } \\
\text { evidence of previous SARS-CoV-2 } \\
\text { infection has been found }\end{array}$ & $8,113,058$ & 6 & $0.7[0.3 ; 1.6]$ \\
\hline First COVID-19 mRNA injection & $4,079,234$ & 5 & $1.2[0.4 ; 2.9]$ \\
\hline Second COVID-19 mRNA injection & $3,905,636$ & 4 & $1.0[0.3 ; 2.6]$ \\
\hline \multicolumn{4}{|l|}{ Vaccination by sex } \\
\hline Males & $4,126,275$ & 8 & $1.9[0.8 ; 3.8]$ \\
\hline Females & $3,986,783$ & 1 & $0.3[0.0 ; 1.4]$ \\
\hline
\end{tabular}

B) Rate of MIS-C following SARS-CoV-2 infection in 12-17-year-old children

\begin{tabular}{llll}
\hline & $\begin{array}{l}\text { Estimated number of } \\
\text { infected children }\end{array}$ & Number of MIS-C & $\begin{array}{l}\text { Rate per } 1,000,000 \text { of } \\
\text { infections }\end{array}$ \\
\hline MIS-C by sex & $1,147,150$ & 130 & $113.3[94.7 ; 134.6]$ \\
Males & 587,086 & 74 & $126.0[99.0 ; 158.2]$ \\
Females & 560,064 & 56 & $100.0[75.5 ; 129.8]$ \\
\hline
\end{tabular}

Abbreviations: MIS-C: multisystem inflammatory syndrome in children. 
Table 3: Comparison of clinic-biological features of hyper-inflammatory syndrome following COVID-19 mRNA vaccine and MIS-C post SARS-CoV-2 infection in France.

\begin{tabular}{|c|c|c|c|}
\hline & $\begin{array}{l}\text { Hyper-inflammatory } \\
\text { syndrome following } \\
\text { COVID-19 mRNA vaccine } \\
(\mathrm{N}=9)\end{array}$ & $\begin{array}{l}\text { MIS-C post SARS- } \\
\text { CoV-2 infection } \\
(\mathrm{N}=199)\end{array}$ & $P$ value \\
\hline \multicolumn{4}{|l|}{ Clinical characte ristics } \\
\hline Sex ratio (F/M) & 0.13 & 0.84 & 0.081 \\
\hline Age & $12.5[12.0 ; 13.5]$ & $8.7[4.8 ; 12.1]$ & \\
\hline \multicolumn{4}{|l|}{$\begin{array}{l}\text { Organ involvement following MIS-C } \\
\text { WHO definition }\end{array}$} \\
\hline Mucocutaneous involvement & $5(56 \%)$ & $159(80 \%)$ & 0.097 \\
\hline Shock & $3(33 \%)$ & $100(50 \%)$ & 0.318 \\
\hline Cardiac involvement & $8(89 \%)$ & $125(63 \%)$ & 0.161 \\
\hline Including LVEF $\leq 55 \%$ & $3(33 \%)$ & $52(26 \%)$ & 0.701 \\
\hline Coagulopathy & $5(56 \%)$ & $82(41 \%)$ & 0.496 \\
\hline Digestive symptoms & $7(78 \%)$ & $178(89 \%)$ & 0.261 \\
\hline \multicolumn{4}{|l|}{ Other organ involvement } \\
\hline Cytolytic hepatitis & $4(44 \%)$ & $36(18 \%)$ & 0.071 \\
\hline Lymphadenopathy & $3(33 \%)$ & $39(20 \%)$ & 0.390 \\
\hline Renal failure & $2(22 \%)$ & $31(16 \%)$ & 0.637 \\
\hline Neurological involvement & $1(13 \%)$ & $65(33 \%)$ & 0.278 \\
\hline \multicolumn{4}{|l|}{ Biological features } \\
\hline Maximal CRP, mg/L & $186.0[97.0 ; 250.0]$ & $271.0[187.2 ; 353.5]$ & 0.031 \\
\hline Ferritinemia, $(\mu \mathrm{g} / \mathrm{L})$ & $527.0[369.5 ; 4892.5]$ & $390.0[206.0 ; 748.5]$ & 0.228 \\
\hline Hemoglobin, $\mathrm{g} / \mathrm{dL}$ & $12.3[11.6 ; 13.6]$ & $11.0[10.1 ; 11.0]$ & 0.022 \\
\hline Leucocytes, /mm3 & $10560[7530 ; 13720]$ & 9945 [7 000; 14.155] & 0.768 \\
\hline Neutrophils, /mm3 & 9400 [5 970; 11350$]$ & 8090 [5 245; 12 065] & 0.940 \\
\hline Lymphocytes, /mm3 & $890[530 ; 910]$ & $1000[690 ; 1805]$ & 0.217 \\
\hline Eosinophils, /mm3 & $220[15 ; 740]$ & $100[5 ; 220]$ & 0.463 \\
\hline Platelets, /mm3 & $230000[204000 ; 321000]$ & $\begin{array}{l}186000[142000 \\
277500]\end{array}$ & 0.336 \\
\hline \multicolumn{4}{|l|}{ Short term outcomes } \\
\hline PICU transfer & $3(33 \%)$ & $143(72 \%)$ & 0.022 \\
\hline Hemodynamic support & $2(22 \%)$ & $86(43 \%)$ & 0.307 \\
\hline Hospital length of stay & $7.0[7.0 ; 9.0]$ & $8.0[6.0 ; 12.0]$ & 0.960 \\
\hline
\end{tabular}

Categorical variables are described with numbers (percentages) and quantitative variables are described with median (IQR). Abbreviations: MIS-C: multisystem inflammatory syndrome in children. 